\title{
Correction to: Effect of Enzyme-Inducing Antiseizure Medications on the Risk of Sub-Therapeutic Concentrations of Direct Oral Anticoagulants: A Retrospective Cohort Study
}

\author{
Amichai Perlman ${ }^{1,2,3} \cdot$ Rachel Goldstein $^{1,2} \cdot$ Lotan Choshen Cohen $^{1,6} \cdot$ Bruria Hirsh-Raccah $^{2,3,4} \cdot$ David Hakimian $^{1,6}$. \\ Ilan Matok ${ }^{3}$. Yosef Kalish ${ }^{5,6} \cdot$ Daniel E. Singer $^{7} \cdot$ Mordechai Muszkat $^{1,6}{ }_{\mathbb{D}}$
}

Published online: 3 August 2021

(c) The Author(s) 2021

\section{Correction to: CNS Drugs (2021) 35:305-316 https://doi.org/10.1007/s40263-021-00795-z}

The article Effect of Enzyme-Inducing Antiseizure Medications on the Risk of Sub-Therapeutic Concentrations of Direct Oral Anticoagulants: A Retrospective Cohort Study, written by Amichai Perlman, Rachel Goldstein, Lotan Choshen Cohen, Bruria Hirsh-Raccah, David Hakimian, Ilan Matok, Yosef Kalish, Daniel E. Singer, Mordechai Muszkat, was originally published Online First without Open Access. After publication in volume 35, issue 3, page 305-316 the author decided to opt for Open Choice and to make the article an Open Access publication. Therefore, the copyright of the article has been changed to (c) The Author(s) 2021 and the article is forthwith distributed under the terms of

The original article can be found online at https://doi.org/10.1007/ s40263-021-00795-z.

Mordechai Muszkat

muszkatm@hadassah.org.il

1 Department of Medicine, Hadassah Hebrew University Medical Center, Mount Scopus, 91540 Jerusalem, Israel

2 Department of Pharmacy, Hadassah Hebrew University Medical Center, Jerusalem, Israel

3 Division of Clinical Pharmacy, Faculty of Medicine, Institute for Drug Research, School of Pharmacy, Hebrew University of Jerusalem, Jerusalem, Israel

4 Department of Cardiology, Hadassah Hebrew University Medical Center, Jerusalem, Israel

5 Department of Hematology, Hadassah-Hebrew University Medical Center, Jerusalem, Israel

6 Faculty of Medicine, Hebrew University of Jerusalem, Jerusalem, Israel

7 Division of General Internal Medicine, Massachusetts General Hospital, Harvard T.H. Chan School of Public Health, Boston, MA, USA the Creative Commons Attribution-NonCommercial 4.0 International License, which permits any non-commercial use, sharing, adaptation, distribution and reproduction in any medium or format, as long as you give appropriate credit to the original author(s) and the source, provide a link to the Creative Commons licence, and indicate if changes were made. The images or other third party material in this article are included in the article's Creative Commons licence, unless indicated otherwise in a credit line to the material. If material is not included in the article's Creative Commons licence and your intended use is not permitted by statutory regulation or exceeds the permitted use, you will need to obtain permission directly from the copyright holder. To view a copy of this licence, visit http://creativecommons. org/licenses/by-nc/4.0/.

The original article has been corrected.

Funding Open Access funding was provided by internal research funding granted to Mordechai Muszkat, M.D. from Hadassah Medical Center, Jerusalem, Israel. 